\title{
InsIDe MCClung J.A.'S “ClOSET" in VRIEND V. ALBERTA: THE INDIGNITY OF MISRECOGNITION, THE TOOL OF OPPRESSIVE Privacy, AND AN IDEOLOGY OF EQUAlity
}

\author{
JAMES R. OLCHOWY
}

Addressing recent expressions of concern about the Supreme Court of Canada's alleged inability to articulate a principled and coherent philosophy of the Charter, the author scrutinizes Vriend $v$. Alberta, a controversial gay-rights case in which starkly antithetical philosophical approaches to the Charter come into focus. While differentiating theoretically between modern and postmodern paradigms of justice, and contracting McClung J.A.' 's majority judgment for the Alberta Court of Appeal with the ruling of the Supreme Court of Canada in Vriend, the author argues that the Supreme Court - guided by the Chartcr's equality provisions - has begun to articulate a postmodern philosophy of the Charter centred on the idea of inclusive justice. This emerging philosophy of inclusive justice is premised on the notion that the law works to produce the reality in which we live. not merely to reflect it.

Whereas, in Vriend, McClung J.A. 's philosophy of the Charter adheres to the assumptions of modern jurisprudence and the concepts of classical liberalism - in particular, concepts such as abstract individualism, the privatelpublic divide, and formal equality - the Supreme Court's philosophy in Vriend is coloured by postmodern insights that cogently impugn McClung J.A.'s traditional assumptions and concepts. What the Supreme Court's position makes clear is that, by resorting to a rhetoric of misrecognition. an ideology of privacy, and an ideology of equality. McClung J.A. tellingly exposes the limitations of his Charter philosophy, which actually reinforces and perpetuates the discriminatory treatment and oppression of sexual minorities in Canadian society.

Juxtaposed with McClung J.A.'s questionable interpretive approach is the Supreme Court's emphasis in Vriend on achieving substantive equality - an emphasis that the author construes as underscoring how the Supreme Court has actually gone some distance toward articulating a credible postmodem philosophy of the Charter. The equality provisions of the Charter exhibit postmodern potential because they enable the Supreme Court to deconstruct McClung J.A.' 's "blind" political liberalism, which depends upon an
En réponse aux préoccupations récentes au sujet de l'incapacité alléguée de la Cour suprème du Canada de formuler une philosophie cohérente de la Charte, l'auteur examine Vriend c. Alberta un cas controversé sur les droits des homosexuels et des lesbiennes, qui a donné lieu à des approches philosophiques radicalemem antithétiques à la Charte. Elablissant une distinction théorique entre les paradigmes de justice modernes et postmodernes, et opposant la décision majoritaire du juge McClung pour la Cour d'appel de l'Alberta et l'arrêt Vriend de la Cour suprème du Canada, l'auteur soutient que cette dernière - guidée par la garantie dëgalité énoncée par la Chartc - a commencé da formuler une philosophie postmoderne de la Charte axée sur la notion de justice inclusive. Cette philosophie émergente repose sur le principe voulant que le droit s'emploie à produire la réalité dans laquelle nous vivons et non seulement à la refléter.

Alors que dans Vriend, la philosophie du juge McClung est conforme aux principes jurisprudentiels modernes et aux notions de libéralisme classique, notamment - individualisme abstrait, distinction privé/public et égalité formelle - la philosophie de la Cour suprème est teintée d'un postmodernisme qui se heurle aux postulats traditionnels du juge McClung. La position de la Cour suprème indique clairement que, en recourant $\dot{a}$ une rhétorique de non-reconnaissance, au motif des activités privées et à une idéologie dëgalité, le juge McClung met en évidence les limites de son interprétation de la Chartc, qui renforce et perpétue en fait le traitement discriminatoire et l'oppression des minorités sexuelles de la société canadienne.

$\dot{A}$ l'interprétation douteuse du juge McClung, s'oppose l'importance accordee au respect des droits à l'égalité véritable dans Vriend démontrant, selon l'auteur, que la Cour suprème progresse vers la formulation d'une philosophie postmoderne de la Charte. Les droits à l'égalité garantis par la Charte se prêtent à une interprétation postmoderne parce qu'ils permettent à la Cour suprème de déconstruire le libéralisme aveugle de McClung, ancré dans une conception idéale et atomistique de lätre humain et dans une 
unencumbered, atomistic sense of the human self and a dubious neutrality. The virtues of the Supreme Court's postmodern approach, which requires careful consideration of what is currently excluded by Canadian legality and justice, are not easily seen within the paradigm of modern jurisprudence, which upholds the law's uniformity, autonomy, and completeness. The Supreme Court's emerging postmodern philosophy of the Charter a philosophy conducive to publicly recognizing and protecting human differences in the name of substantive equality - holds much potential for making the Canadian justice system imaginatively and legally responsive to the hidden needs and marginalized perspectives of disadvantaged citizens and groups. neutralité douteuse. Les vertus de l'approche postmoderne de la Cour suprême, qui mérite un examen attentif de ce que laissent pour compte la justice et le droit canadiens, ne sont pas évidentes au sein du paradigme de la jurisprudence moderne réitérant l'uniformité, l'autonomie et l'exhaustivité de la loi. La philosophie postmoderne émergente de la Cour suprême envers la Charte - une philosophie propice à la reconnaissance publique et à la protection des différences au nom de l'égalité véritable - pourrail bien rendre le système juridique canadien sensible aux besoins cachès et aux perspectives marginalisées des citoyens et des groupes désavantagés.

\section{TABLE OF CONTENTS}

I. Introduction: "All OVER the MAP" - IN SEARCH OF A "DEEP PHILOSOPHY OF THE CHARTER" . . . . . . . . . 649

II. Prologue to VRIEND: PostModern JURISPRUDENCE, THE "PHILOSOPHY OF THE LIMIT," AND "THE OUTSIDER'S STORY" .... 653

III. READING VRIEND IN A POSTMODERN CONTEXT: "BLIND

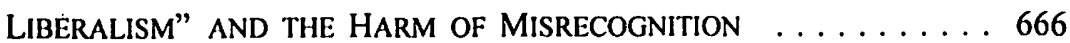

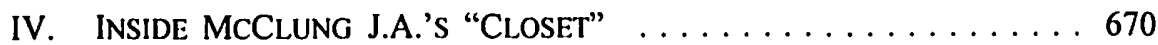

A. Privacy as a tool of Exclusion, Oppression, AND PUBLIC SUBORDINATION $\ldots \ldots \ldots \ldots \ldots \ldots 670$

B. AN ALLEGORY OF DISCRIMINATION:

AN "IDEOLOGY OF EQUALITY" . . . . . . . . . . . . 674

V. THE CHARTER'S CONCEPTUAL DISSONANCE: THE MALAISE OF ABSTRACT, UNENCUMBERED INDIVIDUALISM AND

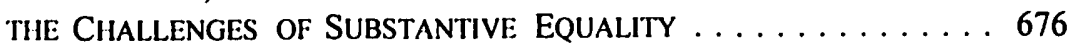

VI. THE SUPREME COURT'S RESPONSE: THE SUPREMACY OF EQUALITY AND A PHILOSOPHY of INCLUSIVE JUSTICE . . . . 678

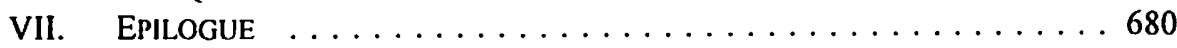

\section{INTRODUCTION: "AlL OVER THE MAP" - IN SEARCH OF A "DEeP PHILOSOPHy OF THE CHARTER"}

In 1998, The Globe and Mail's reporter Kirk Makin, in an article about a conference marking the sixteenth "birthday" of the Canadian Charter of Rights and Freedoms,' offered a disturbing portrait of the Supreme Court of Canada: "A badly divided Supreme Court of Canada is producing a stream of barely comprehensible Charter of Rights decisions that have left lawyers in a state of confusion...." Makin explained his

1 Canadian Charter of Rights and Freedoms, Part I of the Constitution Act, 1982, being Schedule B to the Canada Act 1982 (U.K.), 1982, c. II. [hereinafter Charter].

$2 \quad$ K. Makin, "Legal Experts Slam Top Courts' Charter Decisions," The Globe and Mail (18 April 1998) Al. 
point: "[R]ecent decisions have muddied the waters on the admissibility of evidence, seriously damaged the presumption of innocence and confused issues such as equality rights." ${ }^{3}$ Moreover, in this article and a second one, ${ }^{4}$ Makin identified several prominent legal observers who have expressed frustration with the Supreme Court's decisions: Robert Hubbard (lawyer for the federal Department of Justice), Jamie Cameron (Osgoode Hall law professor), Mark Sandler (Toronto criminal lawyer), Peter Russell (University of Toronto political scientist), Alan Young (Osgoode Hall Law Professor), and Dianne Martin (Osgoode Hall Law Professor).

Why, sixteen years after the advent of the Charter, were so many prominent individuals questioning the Supreme Court's record? The words of Peter Russell offer a plausible answer: "I think a lot of the judges are without a deep philosophy of the Charter."'s Russell's words complement those of Jamie Cameron, whose opinion on two recent cases reflects her own dissatisfaction with Charter jurisprudence:

\footnotetext{
Ultimately, commands that were sacrosanct in Vriend were simply ignored by the court in Lucas. Others may do better, but I can only reconcile the two by observing that equality is in and expressive freedom is out.
}

The juxtaposition of activist and reactionary in these two cases is symptomatic of an entire jurisprudence that is based on reflex, not principle. That is why $\mathrm{I}$, and others, remain unable to make head or tail of it."

Both Russell and Cameron openly regret what they perceive as the absence of a coherent, principled philosophy of the Charter in Canada's highest court. They and others have detected inconsistency and philosophical confusion in the Court's application of the Charter.

To be sure, in the months preceding the Charter's sixteenth birthday, Canada's Supreme Court was frequently in the news and not always for the best of reasons. One could even infer that the Court's carefully cultivated image of detachment was, in a couple of instances, somewhat tarnished by public controversy. Controversy arose, for instance, over the newly appointed Mr. Justice Binnie's allegedly derogatory comments about homosexuals, which "cast a pall over a key pending gay-rights case...." There was also much controversy over the Court's involvement in the Secession Reference. ${ }^{8}$

Considered in the context of Canada's ongoing national debate on the nature and scope of judicial review, such controversies suggest that we live in an age of legalized

\footnotetext{
Ibid.

"Lawyer Says Top Court Deserves Tough Criticism," The Globe and Mail (18 April 1998): A4. As quoted in Makin, supra note 4 at A4.

J. Cameron, "Re Supreme Cour, All over the Map," The Globe and Mail (25 April 1998) D7.

K. Makin, "Binnie's Remarks Draw Activist Fire," The Globe and Mail (14 March 1998) A6.

Reference Re Secession of Quebec (1998), 161 D.L.R. (4th) 385 (S.C.C.) [hereinafter Secession Reference].
} 
politics.' In such an age, Supreme Court decisions are read and wielded as highly political documents that not only reflect partisan political struggles but also, occasionally, trigger debates about the deep political structuring that our Constitution embodies. The issues raised in such an age seem ineluctably political and, ultimately, perhaps philosophical; they are not strictly legal. In an age of legalized politics, public attention focuses on which political and cultural values the Supreme Court upholds and perpetuates in reaching its legal conclusions. Whose values and perspectives are being promoted? Attention shifts from procedural fairness, the hallmark of liberalism, to the Court's philosophy of justice. What vision of Canadian society and humanity does the Supreme Court use the Charter to uphold?

Given the public questioning of the Supreme Court induced by both the Binnie Affair and the Secession Reference, when the Supreme Court rendered its decision on Vriend v. Alberta, ${ }^{10}$ a controversial gay-rights case, what transpired was unsurprising: Canadians were treated to a hot and extended public debate over the permissibility of judicial activism and the viability of the Charter's notwithstanding clause. For those still longing to preserve a strict division between law and politics in Canadian society, Vriend underscored, once again, how fundamental constitutional values and partisan politics have become conflated in Canada's legal system.

In this article, I ask whether the Supreme Court has succeeded - at least to some extent - in articulating a coherent philosophy of the Charter. In addressing that question, I juxtapose and study the Alberta Court of Appeal and Supreme Court of Canada rulings in Vriend. By contrasting these rulings, I foreground matters of legal philosophy and political theory, and scrutinize the Supreme Court's judgment for evidence of a developing philosophy of the Charter.

Assuming that Vriend concerns not only a partisan political debate over gay rights, but also deeper political and philosophical questions crucial to the Charter's application, I begin by exploring a growing body of interdisciplinary literature on postmodernism and postmodern jurisprudence. In the context of such literature, several key themes in Vriend emerge from the shadows--themes related, I would argue, to the Supreme Court's development of a philosophy of the Charter. Those themes are particularly visible when one compares the Charter philosophy espoused by McClung J.A., author of the majority judgment for the Alberta Court of Appeal in Vriend, with the Charter philosophy of the Supreme Court as expressed by lacobucci J., Cory J. and L'Heureux-Dube' J.

After differentiating between modern and postmodern paradigms of justice, I critique McClung J.A.'s judgment in Vriend (C.A.) in several ways. First, I argue that McClung J.A.'s reasoning not only epitomizes the dangerous blindness of classical liberalism and modern jurisprudence but also employs a harmful rhetoric of misrecognition (or nonrecognition) when addressing sexual minorities in Canadian society. Second, I argue

11 Vriend v. Alberta, [1998] I S.C.R. 493 [hereinafter Vriend (S.C.C.)]. 
that McClung J.A. misuses privacy, a value sacrosanct to classical liberals, as a tool of exclusion, oppression, and public subordination. Third, I argue that, by adopting an ideology of equality rather than promoting substantive equality in his judgment, McClung J.A. essentially fashions an allegory of discrimination. Fourth, underscoring how McClung J.A.'s ideologies of privacy and equality reflect and reinforce the discriminatory treatment and oppression of sexual minorities in Canadian society, 1 contend that Vriend sensitizes us to the Charter's internal conceptual dissonance. In particular, Vriend illustrates how the Charter's equality provisions exist in tension with many of its liberal underpinnings.

Ultimately, I contend that the Supreme Court's reasoning in Vriend - reasoning philosophically distinguishable from that of McClung J.A. - demonstrates how the equality provisions of the Charter constitute "a door" through which important postmodern insights can "infiltrate" the Canadian legal edifice. The equality provisions of the Charter exhibit postmodern potential because, as Vriend shows, they enable the Supreme Court to deconstruct a problematic political liberalism dependent upon an unencumbered, atomistic sense of the human self and a dubious neutrality. Although the Charter has fairly been construed as a repository for the concepts of classical liberalism, one notices - by examining the key jurisprudential themes of Vriend in the context of postmodern jurisprudence - the Charter's special capacity for transforming Canadian law into an inclusive rather than an exclusionary mechanism. The Charter's equality provisions, as interpreted by the Supreme Court in Vriend, seem particularly suitable for circumventing problems associated with the kinds of generalizations and categorizations implicit in a legal system whose deep political principles originate in the modern paradigm of classical liberalism.

Recent Charter jurisprudence may understandably confuse and trouble both lawyers and legal scholars. However, the nostalgia such lawyers and scholars express for certainty, predictability and orderly development in the law seems connected to a modern rather than a postmodern vision of jurisprudence. By erecting and sustaining an unreliable boundary between principled applications of the law and political concerns, that modern vision may disregard the unavoidable policy-based aspect of judicial review in our postmodern, pluralist age. Moreover, that modern vision, by preferring a difference-blind approach to equality, does not easily allow marginalized persons who struggle for equal dignity and public recognition to be heard by the courts.

Postmodern thinking, however, is slowly revising the modern legal paradigm traditionally upheld in Canada's liberal polity. By exemplifying how new individual and group-based needs for dignity and recognition may emerge from silence and impinge upon the traditional political values and structures of the Charter, Vriend challenges the deep political project and liberal values of the Canadian Constitution. The Supreme Court's handling of Vriend reveals how the law's inconsistencies and gaps might be overcome through the judiciary's pursuit of an inclusive, postmodern sense of justice in Canada. The Supreme Court, in Vriend, thus goes some way towards articulating a postmodern philosophy of the Charter. 


\section{Prologue to VRIEnd: POSTMOdern Jurisprudence, THE “PHILOSOPHY OF THE LIMIT," AND “THE OUTSIDER's STORY"}

In hopeful moments, it seems plausible to say, as B.W. Powe does in his poetic and visionary $A$ Canada of Light, that "[t]he old Canada is ending";" that Canada is a "state whose lack of a single identity, its lack of homogeneity, may be its destiny." 12 In supporting this postulate, one could assert that Canadians live in a world that is rapidly transforming, a world where inflexible old structures of authority, identity, and meaning are either crumbling or being hastily re-designed to serve new and emergent human needs and circumstances. In intellectual circles, this rapidly changing world is sometimes characterized, rather ominously, by what Jürgen Habermas has referred to as a "legitimation crisis"; in popular culture, Michael Stipe's lyrics in "Losing My Religion" encapsulate, more accessibly, the existential anxiety of the contemporary milieu: "Life is bigger, it's bigger than you, and you are not me."13

The point is not only that, in contemporary culture, "there are no absolute grounds of value which can compel assent," 14 but also that the meaning of human nature has been recognized as indeterminate and historical. As Michel Foucault observes, "[a] certain fragility has been discovered in the very bedrock of existence - even, and perhaps above all, in those aspects of it that are most familiar, most solid and most intimately related to our bodies and to our everyday behaviour." ${ }^{\text {is }}$ In responding to this perceived instability in the concept of human nature, Foucault recommends that we develop a "critical ontology of ourselves," "an attitude, an ethos, a philosophical life in which the critique of what we are is at one and the same time the historical analysis of the limits that are imposed on us and an experiment with the possibility of going beyond them." 16 He connects this recommended analysis with an "impatience for liberty," for he construes us as "beings who are historically determined, to a certain extent, by the Enlightenment." 18

What Habermas, R.E.M., and Foucault collectively allude to is the contemporary world's widespread scepticism about traditional metanarratives, foundational beliefs, and authorities. Jean-François Lyotard calls this scepticism, this "incredulity toward metanarratives,"19 postmodern.

$" \quad$ B.W. Powe, A Canada of Light (Toronto: Somerville House, 1997) at 1.

$12 \quad$ lbid. at 105.

13 R.E.M., "Losing My Religion" from the album Out of Time (Scarborough: Warner Music Canada, 1991).

14 S. Connor, Postmodernist Culture: An Introduction - Theories of the Contemporary, $2 \mathrm{~d}$ ed. (Cambridge, Mass.: Blackwell, 1997) at 8.

is M. Foucault, "Two Lectures" in M. Kelly, ed., Critique and Power, Recasting the Foucaul/Habermas Debate (Cambridge, Mass.: MIT Press, 1994) at 19.

16 M. Foucault, "What is Enlightenment?" trans. C. Porter in P. Rabinow, ed., The Foucault Reader, (New York: Pantheon, 1984) at 50.

$17 \quad$ Ibid.

$18 \quad$ Ibid. at 43.

19 J.-F. Lyotard, The Postmodern Condition: A Report on Knowledge, trans. G. Bennington \& B. Massumi (Minneapolis: University of Minnesota Press, 1984) at xxiv. 
Logically, such scepticism pertains even to the metanarrative of modernist jurisprudence articulated in such works as Kelsen's The Pure Theory of Law (1934) ${ }^{20}$ and H.L.A. Hart's The Concept of Law (1961), ${ }^{21}$ both of which conceive of law as "a complex, autonomous, internally consistent set of norms and rules...." 22 The modernist version of law perpetuates a "predominant strategy": that of weaving "legal texts into a single, seamless veil in which authorized and symmetrical patterns are endlessly produced, circulated and repeated." ${ }^{23}$ But, as Martha Minow has said, such a strategy is now being subjected to rigorous debate: "deeper than ... current affairs topics, there are a series of legal and political debates that signal shifts in generally accepted assumptions about law and society." ${ }^{24}$

Of course, Habermas contends that, through a renewed pursuit of "communicative rationality" in "a self-determining community of free and equal subjects...,"25 we will overcome the limitations of modernist jurisprudence. It is possible, he reasons, for the oppressiveness of modernist culture to be cured through developing discursively healthy democratic processes and institutions. On the other hand, Foucault understands power - including legal power - as productive of knowledge and practice, and as illustrative of "the manifold forms of domination that can be exercised within society." ${ }^{26}$ Foucault sees the force of law as incorrigible insofar as it pursues and manufactures illusions of uniformity and truth; for him, the law becomes irretrievably entangled with the production of relations of inequality within society:

The system of right, the domain of the law, are permanent agents of these relations of domination, these polymorphous techniques of subjugation. Right should be viewed ... not in terms of a legitimacy to be established, but in terms of the methods of subjugation that it instigates. ${ }^{27}$

$\mathrm{He}$ is thus concerned with how human beings are culturally produced and rigorously disciplined within particular systems of power, dominance, and law: "it is already one of the prime effects of power that certain bodies, certain gestures, certain discourses, certain desires, comes [sic] to be identified and constituted as individuals." 28 Foucault's work is complemented by Judith Butler's gender theory: “'sex' not only functions as a norm, but is part of a regulatory practice that produces the bodies it

H. Kelson, The Pure Theory of Law, trans. M. Knight (Berkeley: University of California Press, 1967).

H.L.A. Hart, The Concept of Law (Oxford: Clarendon Press, 1961).

Connor, supra note 14 at 61 .

C. Douzinas, R. Warrington \& S. McVeigh, Postmodern Jurisprudence: The Law of Text in the Texts of Law (London: Routledge, 1991) at ix-x.

M. Minow, "Partial Justice: Law and Minorities" in A. Sarat \& T.R. Kcarns, eds., The Fase of Law (Ann Arbor: University of Michigan Press, 1991) 15 at 17.

25 S.K. White, "Reason, Modernity and Democracy" in S.K. Whitc, ed., The Cambridge Companion to Ilabermas (Cambridge: Cambridge University Press, 1995) at 12-13.

26
Supra note 15 at 34.

Ibid.

Ibid. at 36 . 
governs, that is, whose regulatory force is made clear as a kind of productive power, the power to produce - demarcate, circulate, differentiate - the bodies it controls." 29

Foucault's critique of modernism certainly cuts more deeply than Habermas' does. While Habermas aims to repair and ultimately sustain modernism by eliminating its deficiencies, Foucault prefers to situate himself in the ruins of, or at the margins of, an unsalvageable modernism, imagining new styles of justice that will empower new forms of humanity. Positioned somewhere in between the approaches of these two is Minow, whose interests, while equally sophisticated theoretically, are deliberately much more practical and concrete in focus. Wanting to get trapped neither in the remoteness of theoretical abstractions, nor in a world where particular voices and identities do not count, she argues for the liberating effects of telling stories — individually and collectively - from the margins of an exclusionary legal culture: "New stories describe minority viewpoints as anomalies that test prevailing paradigms." 30 She affirms the need for liberating the legal imagination, and worries about the effeteness of abstract theorizing in isolation from particular human contexts.

Undoubtedly, contemporary thinkers like Habermas, Foucault, Lyotard, Butler, and Minow have shown us how life is "bigger" than authoritative institutions - ones like the law - that presuppose their own autonomy and universality. For all of these thinkers, there are aspects of existence that resist uniformity and consistency, and that inevitably exert pressure from outside or inside established institutions like the law. It is in exploring such resistances to normativity and completeness that "legal postmodernism comes into being with challenges to the unity and coherence of law assumed in previous jurisprudential accounts." 31 The law's inevitable incompleteness and artificiality - and especially its oppressive generalizing tendencies - are exposed through its frequent failure to recognize "the distance in your eyes," 32 and through its habitual failure to admit that "[t]he notion of a universality of human experience is a confidence trick...." 33

In postmodern jurisprudence, such failures are actively avoided. The universality of human nature is replaced by a new sensitivity to otherness, human self-creation, and human diversity: "the critical edge of postmodernity's deconstructing of the modern universalizing tendency comes from its awareness of the value and significance of respecting difference and otherness." ${ }^{34}$ That sensitivity to difference and otherness is pivotal to "the ethics and politics of reading the law in an age of uncertainty."

J. Butler, Bodies that Matter: On the Discursive Limits of "Sex" (New York: Routledge, 1993) at 1.

Supra note 24 at 20.

Connor, supra note 14 at 64 .

R.E.M., supra note 13.

A. Carter, The Sadeian Woman: An Lixercise in Cultural History (London: Virago, 1979).

J. Natoli \& L. Hutcheon, "Introduction: Reading A Postmodern Reader" in J. Natoli \& I. Hutcheon, eds., A Postmodern Reader (Albany: State University of New York Press, 1993) vii at $\mathrm{x}$.

3 Douzinas, Warrington \& McVeigh, supra note 23 at ix. 
To some individuals - and some judges - the contemporary world, with all its ontological insecurity, is frighteningly full of destructive indeterminacy and disorder; to others, like Foucault and Minow, it is an unsettled world replete with opportunities for exploring constructive social change and liberty, and celebrating human diversity and creativity. In an unsettled, fragmented world, the formerly hegemonic or "universal" culture gradually loses its dominance, thus creating space for new meanings, alternative lifestyles, and the politics of difference. In a fragmented world, new voices are more easily invented and heard; the myths of human uniformity and human limitation are exposed as the oppressive ideas and ideals that they are.

Regardless of the critical stance one adopts, it seems incontestable that our world is lurching toward the postmodern, which is "no more ignorable than is the air we breathe..."; ${ }^{36}$ our world is a world where the shifting boundaries of human knowledge remain constantly visible; it is a world where human nature loses its tyrannical fixity, acquiring a liberating plasticity that allows for a diversity of forms and identities. When no longer construed as replicas of an invariable, universal mould called "human nature," human beings are freed from normativity and a morality of obedience. In response to this release, our postmodern ethos, as many commentators contend, reaches for the complex ethical relation inferable from Stipe's clause "you are not me,"37 and for a more complex understanding of equality and personhood than that which is associated with traditional liberal notions of abstract individualism, personal autonomy, and formal equality.

Liberalism, since it is founded on such notions, has been undergoing a philosophical crisis; its conceptual apparatus has become politically and legally shaky in a postmodern world. The clause "you are not me" implies what liberalism sometimes forgets: it implies, through an implicit comparison and an acknowledgement of complex otherness, an unavoidable human intersubjectivity, ${ }^{38}$ and the necessity of what James Boyd White calls "justice as translation":

Translation forces us to respect the other - the other language, the other person, the other text - yet it nonetheless requires us to assert ourselves, and our own languages, in relation to it. It requires us to create a frame that includes both self and other, both familiar and strange; in this I believe it can serve as a model for all ethical and political thought. ${ }^{39}$

Natoli \& Hutcheon, supra note 34 at viii.

R.E.M., supra note 13.

What I mean is well explained by G. Lakoff \& M. Johnson in Metaphors We Live By (Chicago: University of Chicago Press, 1980) at 232:

The capacity for self-understanding presupposes the capacity for mutual understanding ... Self-understanding seems prior to mutual understanding, and in some ways it is. But any really deep understanding of why we do what we do, feel what we feel, change as we change, and even believe what we believe, takes us beyond oursclves. Understanding of ourselves is not unlike other forms of understanding - it comes out of our constant interactions with our physical, cultural, and interpersonal environment.

J.B. White, Justice as Translation: An Essay in Cultural and Legal Criticism (Chicago: University of Chicago Press, 1990) at xvii. 
Human beings can no longer credibly assume that their identities are self-sufficient and inwardly generated; moreover, people no longer appear to emulate (if ever they actually did) just one vision of human nature or the good life. White's notion of justice as translation responds to that fact. It is a notion that implicitly acknowledges and celebrates human differences, as well as an ethical relation between self and other that makes for an inclusive, helpful, non-coercive human community.

White's approach, in fact, combines well with Drucilla Cornell's affirmation of the legal importance of "the relationship of the philosophy of the limit to questions of ethics, justice, and legal interpretation." "This "philosophy of the limit," conventionally known as "deconstruction," is ethically motivated by the desire to show that all "coherent," complete systems are exclusionary, and that there is always an "other" to the system one happens to be relying upon or trapped within. In showing that deconstruction is much more than the nihilistic creed that its critics declare it to be, Cornell reveals the ethical dimension of the philosophy of the limit. She shows that closed, supposedly consistent, comprehensive structures of justice are actually mechanical, coercive, and unjust. She illustrates how deconstruction actually becomes justice in a postmodern world by explaining how such structures are "contradictorily coherent" and how "coherence in contradiction expresses the force of a desire."

Clearly, while attempting to develop the sort of critical ontology of ourselves recommended by Foucault, both Cornell and White, like Minow, have fashioned readings of justice that focus on the significant boundaries or limits of modern legality; they implicitly acknowledge the necessity of accommodating and respecting human differences through the ongoing ethical interpretation, application, and revision of established law. In making justice responsive to the politics of difference, they not only acknowledge but affirm the relativistic, pluralist context in which we live, and its effects on the meaning and pursuit of justice and equality for everyone. In effect, by exploring and developing our capacity to think about our legal thinking, and what remains outside (or repressed by) our legal thinking's presumed coherence, they engage in a kind of meta-legal analysis that problematizes the modernist belief in a deeper truth or universal reality.

Cornell's telling point, which mingles happily with White's concept of "justice as translation" and Minow's "outsider's story," is that in a postmodern world we must develop "a truly nonviolative relationship to the other...." Instead of defining legality as rule-driven absoluteness characterized by exclusionary practices and airtight definitions, she recommends developing a legality modified continually by an inclusive justice of responsive caring. This caring acknowledges the social interdependence and needs of selves that differ from each other.

"J. Derrida, "Structure, Sign, and Play in the Discourse of the Human Sciences," in Writing and Difference, trans. A. Bass (Chicago: University of Chicago Press, 1978) at 279. 
Cornell distinguishes between modernism and postmodernism in this way: "the 'postmodern' should be understood as an allegory and ... as such, it represents an ethical insistence on the limit to 'positive' descriptions of the principles of modernity long-elaborated as the 'last word' on 'truth,' 'justice,' 'rightness,' etc." ${ }^{\prime 3}$ Her comment and approach are echoed by Douzinas, Warrington, and McVeigh in their differentiation between modern and postmodern politics:

\begin{abstract}
Politics always involves the need to judge. In modern politics, however, judging imposes the idiom of one of the parties to the dispute on the other, the different and the marginal who are denied their separateness and specificity. And if no possibility exists of translating the different languages into some common tertium, these people and groups that have no power to establish their interests will always remain unrepresented and unrepresentable. Thus, whilst we cannot avoid judging, we must abandon the existing languages of judgment because they cannot register the voice of the other. The political project of postmodernism ... is to create a theory of justice, while maintaining total opposition to all totalising techniques. ${ }^{44}$
\end{abstract}

In reaching for postmodern jurisprudence, then, one is advised to attend to the limits of any system of legality; through such attentiveness, legal self-reflexivity emerges as a necessary prelude to legal understanding.

As Cornell stipulates in elaborating upon her self-reflexive philosophy of the limit, the "emphasis on the limit and ... on the portrayal of justice as aporia is crucial to ... marginalized groups whose well-being and very lives may depend on legal transformation." 45 Tellingly, the two groups to which she specifically alludes are women and homosexuals; her philosophy of the limit, not unlike White's "justice as translation" in its motivations, thus serves to underscore "the crucial importance of questions of sexual difference to problems of justice and legal interpretation." ${ }^{46} \mathrm{We}$ shall see, shortly, in the example of Vriend, how questions relating to sexual orientation have exposed "problems of justice and legal interpretation" - and hence problems of legal philosophy - in the Canadian context.

Aside from recognizing what White, Cornell, and Minow recommend with respect to justice in a postmodern world, and what their understanding of justice means for marginalized groups and individuals who are oppressed by dominant, exclusionary models of legality, one inevitably notices that the contemporary world's rich potentiality has been celebrated and articulated by many artists, including contemporary British novelist Jeanette Winterson, who insightfully remarks upon the liberating effects of a protean selfhood:

Human beings are capable of powered flight; we can travel across ourselves and find that self multiple and vast. The artist knows this; at the same time that art is prising away old dead structures that have 
rusted almost unnoticed into our flesh, art is pushing at the boundarics we thought were fixed. The convenient lies fall; the only boundaries are the boundaries of our imagination. ${ }^{47}$

Emphasizing the need to escape boundaries and "dead structures that have rusted almost unnoticed into our flesh...," Winterson's thinking complements the jurisprudential concerns of White, Cornell, and Minow, and intersects with the critical project recommended by Foucault. ${ }^{48}$ In the context of jurisprudence, Winterson's image of dead structures embedded in human flesh is important, for the image signifies how the law impresses itself upon human bodies: it integrates itself with the flesh; it is more than a cerebral phenomenon. Moreover, her image recalls a reverberant remark by another writer, Angela Carter: "[f]lesh comes to us out of history; so does the repression and taboo that governs our experience of flesh." ${ }^{\text {"49 }}$ As Butler puts it, "what constitutes the fixity of the body, its contours, its movements, will be fully material, but materiality will be rethought as the effect of power, as power's most productive effect." 50

Winterson, Carter, and Butler affirm the complexity and alterability of the human self, as well as the inseparability of mind and body in a postmodern world permeated by regulatory norms. In such a world, unimaginative, rule-bound modernist judges with a Cartesian bent - those rather too easily seduced by the objectivity, neutrality, and completeness of their own legal reasoning and fleshly desire - must learn to attend to the liberating effects of storytelling, as well as to the partiality and incompleteness of all narratives, grand theories, and regulatory practices. In a postmodern world, moreover, even the hidden flesh of judges is recognized as created/regulated within history, and as connected to "rationality" and the social network of power in which they participate. Regulatory norms speak through judges even as judges apply the law. This holds even though a legality founded upon political liberalism, which relies upon a reductive mind-body dualism, essentially requires legal thinkers to forget that bodies "generate what is new, surprising, unpredictable," extending "the frameworks which attempt to contain them...." resistances to and perpetuation of regulatory ideals, has been effaced through the blindness of liberalism.

Like litigants, judges have bodies and desires; like litigants, judges are products of history. Flesh counts: in its materiality it may embody and perpetuate regulatory norms; or it may resist the codes and ideals it is expected to obey. Usually some curious combination of embodiment and resistance is to be found, as there is a "materiality that persists beyond any attempt to conceptualize it. ${ }^{152}$ In a world where the human self is protean, and where the law is a human construction embroidered or tattooed upon the

J. Winterson, Art Objects: Essays on Ecstasy and Effrontery (Toronto: Vintage Canada, 1995) at 116.

lbid.

Supra note 33 at 11.

Supra note 29 at 2.

E. Grosz, Volatile Bodies: Toward a Corporeal Feminism (Bloomington: Indiana University Press, 1994) at ix.

32 Natoli \& Hutcheon, supra note 34 at 1. 
flesh with all the symbolism of a scarlet letter, judges should remember their humanity's madeness; they should not allow the "hood of office" to transform them into insensate objects of a mechanical process. They must retain an imaginative capacity for hearing stories told from the sometimes unfamiliar perspectives of particular litigants. And those particular litigants, like Hester Prynne, a fictional character in Hawthorne's The Scarlet Letter, ${ }^{53}$ must imaginatively resist the damning, universalizing, sexist definitions of the scarlet letters written upon their flesh by a closed, unimaginative justice system intent on generating meaning and order through exclusionary practices.

Given the sea of textuality in which humans are ineluctably immersed, both mentally and physically, literature and its unstoppable imaginative resources cannot any longer be construed as irrelevant to the "rationality" of law (despite what many law professors imply when they reward regurgitation): "[m]eaning is never fully closed. In every complex text or discourse, there is always the possibility of telling things otherwise." 54 Hence, as the artfulness of Hawthorne's Hester Prynne demonstrates, it remains possible to embroider one's way out from within the "ideal" enclosure psychologically and physically imposed upon one by the stigma and "legality" of the law's scarlet letters. Having been cruelly condemned and ostracized because of her "adultery" with an unknown man whom she will not publicly expose or betray, Hester works and writes her way back into human society; in the process, she begins to transform that society into a more inclusive community. She employs her imagination to infiltrate and undermine an oppressive culture; as representative of what her society's justice excludes from itself - the freedom of desire - she makes the scarlet letter that she must wear generate new meanings, meanings that subvert those intended by a community intent on using the law to institute moral condemnation and ostracism.

What I am getting at is that the jurisprudential concerns of White, Cornell, and Minow - in the context of Foucault's "impatience for liberty" - should be understood in the context of an interdisciplinary paradigm-shift reflective of our postmodern condition. This is a paradigm-shift that thoroughly investigates cultural presuppositions and recognizes openings for human resistance to unjust laws and legal systems. This is a paradigm-shift that makes the literary imagination vitally important to an understanding of the law, and especially to an understanding of how a particular understanding of human nature is reproduced through the law's regulatory effects.

Clearly, artists like Winterson, Carter, and Hawthorne - through deconstructing the mind-body dualism that Western culture has inherited from the Enlightenment accomplish an imaginative and conceptual task highly relevant to thinking about justice and human subjectivity in a postmodern context. ${ }^{\text {ss }}$ Their work, intertextually understood, enables us to see more easily how law's traditional categories and concepts, often absorbed painfully into the flesh in the form of coercive regulatory structuring,

To see how deeply ingrained this mind-body dualism is in Charter jurisprudence, one need look no further than the reasoning of Lamer C.J.C. in $B(R)$ v. Children's Aid Society of Metropolitan Toronto, [1995] l S.C.R. 315, 26 C.R.R. (2d) 202. 
must begin accommodating the meaningful productivity of resistant human imaginations and bodies. Imaginations and bodies should not be relegated to the safety of a "cordoned off" private sphere or "reserve," while the legal system mechanically churns out its "public" judgments. Rather, what is implied in a shift from modernism to postmodernism, in the notion of "justice as translation," and in justice as "the philosophy of the limit" is that we must enter the law as whole people, with our imaginations and bodies, which are inseparable from the legal arguments to be developed and exchanged. Not to do so is to live a lie, as the Reverend Arthur Dimmesdale does throughout much of Hawthorne's The Scarlet Letter. He slowly dies from self-division and fear while hidden in the closet of a privacy imposed both externally and internally. He suffers punishment and oppression inwardly because his deepest feelings of sexual love, through lack of public recognition and acceptance, have led to his imprisonment. His world or his desire? That is the impossible choice he must make. Both amount to death. His imprisonment within his self and body exemplifies "the materialization of the regulatory norm." 56

Clare Dalton aptly characterizes the interdisciplinary paradigm-shift represented by postmodernism in an essay committed to deconstructing contract law:

Law, like every other cultural institution, is a place where we tell one another stories about our relationships with ourselves, one another, and authority.... Since our stories influence how we imagine, as well as how we describe, our relationships, our stories also limit who we can be. ${ }^{57}$

As she states, the discourse of law, like that of literature, is constitutive of human identities and relationships; neither law nor literature provides a transparent window on a human reality or human nature that pre-exists language and textuality. James Boyd White, our theorist of "justice as translation," agrees with her:

[T]hrough its form of language and of life the law constitutes a world of meaning and action: it creates a set of actors and speakers and offers them possibilities for meaningful speech and action that would not otherwise exist; in so doing it establishes and maintains a community, defined by its practices of language. ${ }^{\text {s }}$

The language of law, then, does not reflect a pre-linguistic, pre-cultural, or fully predetermined understanding of justice; rather, legal discourse, through the limited stories it tells and hears, creates a given culture's understanding of justice and humanity. That discourse even catalogues what kinds of human beings we are permitted to be. As Minow argues, "law itself is unavoidably political. Society makes choices through law about what to value, what to permit, what to punish and what to prohibit. These choices

\footnotetext{
st. Butler, supra note 27 at 2.

57 C. Dalton, "An Essay in the Deconstruction of Contract Doctrine" in S. Levinson \& S. Mailloux, eds., Interpreting Law and Literature: A Hermeneutic Reader (Evanston, Illinois: Northwestern University Press, 1988) 285 at 285. 
include rules about what kinds of changes can be contemplated and how those changes are to be debated and evaluated." 59

If, then, the law is functionally exclusionary, this fact stems from the limited stories it allows itself to understand and tell. Perhaps it is telling the same story over and over again, and we are effectively being lulled into acquiescence by nursery rhymes of legality? There is a dangerous security and certainty inherent in knowing what "the story" is and in knowing that it will always end in the same way. Such repetition becomes imprisonment. Such narrative security and certainty rely upon the "reiterative power of discourse to produce the phenomena that it regulates and constrains...." ${ }^{60}$ In response to such dangerous certainty, Minow herself pursues an expansion of storytelling and imagination within the law: "I am interested in people who have not been the central subjects of theories of law, people who have lived in law's shadows." ${ }^{\prime 61}$ Let us tell and hear some new stories, she seems to say.

In Jeanette Winterson's world of potentiality, where textuality and knowledge - like human flesh - cannot be contained by book covers, censored by judicial "objectivity," or restricted by the metaphysics of mind-body dualism; where alternatives are genuinely imaginable on personal and cultural levels; where meanings proliferate in interdisciplinary dialogues - in this complex, diverse, transformable postmodern world there exists a persistent need to distinguish between legality and justice, as Jacques Derrida has recommended. ${ }^{62}$ This need requires not only that we recognize the limits of the existing legal system's stories, but that we acknowledge the existence of "a beyond" to that system's entrenched rules, principles, and concepts. This "beyond" is what Derrida conceptualizes as an "aporia"; it is what Minow refers to as "the outsider's story." It is a beyond, like death, that marks an incompleteness in our understanding; it is a beyond that we recognize once we realize that "[ $[\mathrm{t}] \mathrm{he}$ texts of law are shown to be subject to the laws of text."63

What the "beyond" ultimately draws attention to is the tension between formal and substantive equality in contemporary jurisprudence. This tension, as Axel Honneth puts it, forces legal thinkers "to confront the question of the relation between the modern idea of equal treatment and the moral principle of care." become philosophical and ethical, and to ask Minow's question: "what do contemporary developments in jurisprudence mean for people who historically have been marginalized by law and legal theory?"65

Supra note 24 at 29.

Butler, supra note 29 at 2.

Supra note 24 at 15.

J. Derrida, "Force of Law: The 'Mystical Foundation of Authority" (1990) 11 Cardozo L. Rev. 919 at 959.

C. Douzina and R. Warrington with S. McVeigh, "Introduction" in Postmodern Jurisprudence: The Law of Text in the Texts of Law (London: Routledge, 1991) xii.

A. Honneth, "The Other of Justice: Habermas and the Ethical Challenge of Postmodernism" in S.K. White, ed., The Cambridge Companion to Habermas (Cambridge: Cambridge University Press, 1995) 289 at 315.

Supra note 24 at 15. 
In drawing together this diverse collection of thinkers - Habermas, Foucault, R.E.M., White, Cornell, Winterson, Carter, Hawthorne, Derrida, Butler, Minow, Douzinas, etc. - my objective has been to prepare the way for a deconstructive reading of Vriend in the context of postmodern jurisprudence. In many ways, Vriend is a case that excellently reveals the need for White's "justice of translation," Cornell's "philosophy of the limit," and Minow's "outsider's story." Vriend is a case that ethically pressures legal thinkers into noticing and comprehending the ideological implications of gaps and silences perpetuated by the dominant discourse of law, which still heavily relies on a modernist jurisprudential outlook. Vriend pressures legal thinkers, moreover, to re-consider what kinds of people are and are not, as the Marxist scholar Althusser would have put it, "interpellated" or "hailed" by the law as we know it. ${ }^{66}$ To whom does the law address itself? Whom does the law fail to address? What does the law say, and what does it leave unsaid? These primary questions, which I would argue have deep philosophical implications for Charter jurisprudence in Canada, are raised directly by Vriend.

Vriend is also a case that asks us to consider the blindnesses of the liberal political philosophy underpinning Canadian jurisprudence. This philosophy tends to perpetuate a particularly abstract style of thinking about human individuals. ${ }^{67}$ Vriend serves additionally as an implicit commentary on how the human body figures in Canadian law, and how the human body may produce meanings outside/beyond/within the law that can ultimately challenge and transform the law. Finally, Vriend succeeds in showing how the Charter - particularly in its equality provisions and the contextual

R. King, "Interpellation" in I.R. Makaryk, ed., Encyclopedia of Contemporary Literary Theory: Approaches, Scholars, Terms (Toronto: University of Toronto Press, 1993) at 566-67.

M. Ramsay in What's Wrong with Liberalism? A Radical Critique of Liberal Political Philosophy (London: Leicester University Press, 1997) at I, offers a general description of liberal democracies: Typically, liberal democratic systems claim to respect the intrinsic worth and dignity of each human being and to embody a commitment to the importance of individual freedom. They seek to limit government power and to safeguard civil liberties. They hold dear the rights to freedom of speech, expression, religion and association, the right to vote and to participate in a competitive party system. To varying degrees, they uphold the right to own, use and dispose of property and extol the virtues of free choice, private enterprise and the market.

Charles Taylor in "Cross-Purposes: The Liberal-Communitarian Debate" in

Philosophical Arguments (Cambridge, Mass.: Harvard University Press, 1995) at 186, adds the following commentary on liberal societies:

[liberalism] sees society as an association of individuals, each of whom has a conception of a good or worthwhile life and, correspondingly, a life plan. The function of society ought to be to facilitate those life plans, as much as possible and following some principle of equality. That is, the facilitation ought not to be discriminatory, although there is obviously some room for serious question as to exactly what this means: whether the facilitation ought to aim at equality of results, resources, opportunities, capacitics, or whatever. But many writers seem to agree on the proposition that the principle of equality or nondiscrimination would be breached if society itself espoused one or another conception of the good life.... Thus, it is argued, a liberal society should not be founded on any particular notion of the good life. The ethic central to a liberal society is an ethic of the right rather than the good. That is, its basic principles concern how society should respond to and arbitrate the competing demands of individuals. These principles would obviously include the respect of individual rights and freedoms, but central to any set that could be called liberal would be the principle of maximal and equal facilitation. 
analysis they inspire - is gradually, albeit haltingly, importing an ethic of care into a legal system of abstract rules and principles. To the extent that the equality provisions are causing Canadian law to evolve and become more inclusive with respect to minorities, these provisions represent, I would argue, the surest door, in the Canadian context, to the insights of postmodern jurisprudence and the development of what Cornell refers to as a "nonviolative relationship with the Other."

As I proceed to my analysis of Vriend, then, I wish to emphasize that the air of rightness, neutrality, and self-sufficiency expressed and promoted by modernist jurisprudence in a liberal democratic society like Canada must be incessantly subjected, in a postmodern context, to otherness, difference, contingency, and pluralism, if justice itself is to inform, supplement, and moderate the legal ordering in which we exist. This point is what Vriend underscores in a most powerful way, especially when one considers the oppressive interpretive strategies employed in the "story" told by McClung J.A. of the Alberta Court of Appeal. Why this point is crucial is evident in what Goodrich, Gouzinas, and Hachamovitch have stated with respect to the meaning of "justice":

The law is committed to generality and uniformity, it calculates those it judges according to their broad similarities and differences, and attempts to subsume them to a rule as instances of its application or to distribute them according to the regularities of a norm. But the justice of the judgment will depend on law's answer to the unique and singular demands of the person who comes to the law. ${ }^{(1)}$

Rather than succumbing to the inertia of fixed, abstract, absolute laws and to the myth of law's universality, our judges must learn to "read in" justice between the lines, through ongoing and purposeful legal interpretation and revision. Yet there also should be agreed upon checks and balances with respect to the kind of reading that occurs the sorts of checks and balances that render justice deliberative and dialogic rather than monological. In this connection, Patrick Monahan's democratic-communitarian conception of judicial review seems apposite:

Judicial review is said to be necessary in order to rein in the totalitarian impulses of the community. The judiciary is instructed to create and police a zone of individual autonomy which is placed beyond the reach of the unwashed mob. In my view, this attempt to create artificial boundaries around the legitimate scope of democratic debate and dialogue is mistaken. 1 argue for a programme designed to embrace politics rather than to turn away from it. The ambition and point of my theory is to reduce the barriers around political argument rather than to reinforce those barriers. I argue that there should be no set of social or political arrangements arbitrarily or permanently insulated from democratic debate and argument. The point is to increase the possibility of revision in social life, rather than to

(.* Cornell, supra note 40 at 13.

(9.) P. Goodrich, C. Douzinas \& Y. Hachamovitch, "Introduction: Politics, Ethics and the Legality of the Continent" in C. Douzinas, P. Goodrich \& Y. Hachamovitch, eds., Politics, Postmodernity and Critical Legal Studies: The Legality of the Continent (London: Routledge, 1994) 1 at 22. 
freeze into place a partial and provisional set of social arrangements. All aspects of social life should be subject to the revisionary potential of politics. ${ }^{70}$

Judicial decision-making, which unavoidably constitutes an "allegory of reading,"71 must appreciate the generative effects of legal reading and textuality within particular contexts. Judgments must not get trapped in a prison of mechanical repetition buttressed by passive, unimaginative, or superficial reading, which involves the withdrawal from critical evaluation; rather, in retaining an openness to "the beyond," judgments must allow for imagining how legality might be made more inclusive and attentive to particular situations and flesh-and-blood individuals, whose needs will change with history. That sort of legal imagining necessitates the fashioning of judges and lawyers who are interactive readers and writers of integrative legal texts. Only through such interactive, imaginative reading and writing can judges release the subjugated knowledges and perspectives of human experience, and make the law into an instrument for maximizing the liberty and equality of all. Ultimately, it is critical that those who write legal judgments learn to appreciate that which is excluded or rendered invisible by the present system of law and power. This kind of appreciation is something that, as we shall see, McClung J.A. rejects in Vriend.

If contemporary Canada constitutes a society fittingly understood as postmodern, and postmodern insights are already busily contesting and even undermining the internal self-sufficiency of a modernist jurisprudence grounded on monological discourse and univocal "Truth," then the limitations and lacunae of our legal system are certainly in need of assessment. This is especially so when our legal system is assumed to be a closed, static structure of rules that easily assimilates all possible fact-situations. In warning of the dangers of closed and static systems of law, Cornell contends:

[L]aw cannot be reduced to a set of technical rules, a self-sufficient mechanism that pulls us down the track through each new fact situation. Law ... cannot be reduced to a self-generated and self-validating set of cognitive norms. Interpretation always takes us beyond a mere appeal to the status quo. ${ }^{72}$

To view our legal system as perfectly rational, internally coherent, and complete as modernist jurisprudence encourages us to do - is to grant our system of law the appearance of naturalness, inevitability, comprehensiveness and "Truth." To do so is to overlook the postmodern, historical insight that "[human] experience is always, if not actually determined, then at least interpreted in advance by the various structures of understanding and interpretation which hold at particular moments in particular societies...."? To understand Canadian law as a self-enclosed, internally consistent, and total system of logic that automatically and transparently renders predictable answers to legal questions - to do so is not only to view law as a kind of infallible,

P. Monahan, Politics and the Constitution: The Charter, Federalism and the Supreme Court of Canada (Toronto: Carswell, 1987) at 103-104. 
metaphysical truth-machine, but also dangerously to ignore or suppress the history and artificiality of the particular knowledge structures and concepts upon which our vision of legality has been built. If we submit to such ignorance, the law, together with its governing concepts, becomes reified, inevitably to the appreciable detriment of those whose identities, desires, and realities have been either marginalized or excluded from the reigning discourse of law.

\section{REAding VRIEND IN A POSTMOdeRn CONTEXT: "Blind LIBERALISM" AND THE HARM OF MISRECOGNITION}

In my extended theoretical prologue, I have taken much time in arriving at Vriend, but I trust that my reasons for doing so are sufficiently important to justify the journey. An understanding of what is going on in and around Vriend requires more than a halfpage case brief. Moreover, by reading Vriend in the context of postmodernism and recent legal theory, one begins to understand what sorts of philosophical questions it might be useful to pose with respect to Canada's Supreme Court.

Clearly, it is within the ethos of postmodernism, which recognizes the constructedness and incompleteness of all knowledge systems, including legal ones, and the "role of representation in maintaining relations of power,",74 that a case like Vriend is best interpreted. This controversial case demonstrates how the Canadian legal system responds to structural gaps and inconsistencies, particularly those that emerge because of the imperfect fit between provincial human rights legislation and the Charter. Vriend also shows that the legal system can be manipulated by judges who intend to further limited visions of what it means to be human.

What is critical is that Vriend brings forward for consideration an "otherness" that has generally gone unrecognized or misrecognized by the law: the otherness of gays and lesbians, whose lives challenge societal stereotyping and prejudices about such concepts as gender, sexuality, and sexual orientation. Donald Casswell has recently commented aptly on how Canadian law has generally functioned to perpetuate and legitimize discrimination against gay men and lesbians:

[T] he heterosexual individual and the heterosexual family are the paradigms upon which Canadian law is based. The assumption is simply that everyone is heterosexual. Many aspects of Canadian law treat lesbians and gay men differently than heterosexuals, either because of the law's substantive content or its application in practice by the courts and tribunals.... To the extent that Canadian law continues to be based on heterosexist assumptions and continues to privilege heterosexuals ahead of lesbians and gay men, it reinforces, perpetuates and legitimizes heterosexual privilege and contributes to homophobia in general and homophobic violence in particular. ${ }^{\text {s }}$

75 D.G. Casswell, Lesbians, Gay Men and Canadian Law (Toronto: Edmond Montgomery, 1996) at 13. 
Casswell's assessment of the state of Canadian law is telling and troubling, especially if one accepts the postmodern premise that the law's definitions and representations are not merely reflective but also productive of the reality within which we must live.

Alongside Casswell's work stands the work of Nancy Fraser, an American feminist who has recently developed an important theory of injustice centred on the concept of misrecognition. Writing of "the irreducibility of heterosexist oppression and the moral legitimacy of gay and lesbian claims"76 within Western culture, Fraser delineates the incapacitating effects of cultural misrecognition on sexual minorities. When combined with Casswell's assessment of the Canadian legal system's historical blindness to the needs of gays and lesbians, her theory of injustice is cogent:

To be misrecognized ... is not simply to be thought ill of, looked down on, or devalued in others' conscious attitudes or mental beliefs. It is rather to be denied the status of a full partner in social interaction and prevented from participating as a peer in social life - not as a consequence of a distributive inequity (such as failing to receive one's fair share of resources or 'primary goods'), but rather as a consequence of institutionalized patterns of interpretation and evaluation that constitute one as comparatively unworthy of respect or esteem. When such patterns of disrespect and disesteem are institutionalized, for example, in law, social welfare, medicine, and/or popular culture, they impede parity of participation, just as surely as do distributive inequities. The resulting harm is in either case all too real. ${ }^{n}$

Fraser's theory on the injustice of misrecognition is an ideal departure point for a close, deconstructive reading of Vriend, for she identifies the special kind of harm that Delwin Vriend suffers when his discrimination claim is rejected by the Alberta Human Rights Commission because of an underinclusive statute. Fraser's theory underscores why a politics of recognition is important to any kind of social ordering and to any meaningful understanding of equality. Moreover, it is easy to see how such a politics of recognition could potentially serve, in a constitutional democracy like Canada, to modify the blind liberalism and abstract individualism by which Canada's Charter jurisprudence tends to be governed.

In identifying misrecognition (or nonrecognition) as a special kind of harm, Fraser assists us in recognizing the "deep philosophy" of the Charter that the Supreme Court of Canada seems slowly to be developing, at least in its equality jurisprudence. The idea that political misrecognition is harmful, because it inhibits an individual's (or a group's) capacity to participate fully and equally in society, is certainly a powerful one. This sort of harm seems somewhat affiliated with the kind of secondary harm mentioned in $R$. v. Butler, ${ }^{78}$ where violent pornography is construed as inhibiting the equal participation of women and children in Canadian society.

lbid.

78 R. v. Butler, [1992] I S.C.R. 452 [hereinafter Butler]. 
In work similar to that of Fraser, at least in respect of the concept of public recognition, the Canadian political philosopher Charles Taylor has advocated that we overcome a barren liberalism that contains no concept of citizen participation and recognition at its core. Like Fraser, he understands the special harm produced in a society, or a legal system, that functions without encouraging the participation and recognition of certain members of the population:

The thesis is that our identity is partly shaped by recognition or its absence, often by the misrecognition of others, and so a person or group of people can suffer real damage, real distortion, if the people or society around them mirror back a confining or demeaning or contemptible picture of themselves. Nonrecognition or misrecognition can inflict harm, can be a form of oppression. imprisoning someone in a false, distorted, and reduced mode of being. ${ }^{79}$

Taylor asserts that, culturally, we need to re-acquaint ourselves with the dialogical character of human life "that has been rendered almost invisible by the overwhelmingly monological bent of mainstream modern philosophy." ${ }^{10}$ This entails recognizing that our individuality is generated not in isolation from others, but in the context of society and human interaction. It is because of this inexorably social dimension of individuals that a "politics of equal recognition" becomes so vital to contemporary democracies. To misrecognize or exclude someone culturally or politically is to undermine society's basic commitment to equality. Hence, Taylor proposes that we graft the concept of equal recognition onto our understanding of what it means to participate fully as a citizen in Canadian society.

What Casswell, Fraser, and Taylor gesture towards - the need for a politics of difference and recognition - is pertinent to the fact-situation that unfolds in Vriend, where a homosexual teacher, fired for being a homosexual, has no legal redress because of the underinclusiveness of Alberta's human rights legislation. By not including sexual orientation as a head of discrimination in its human rights legislation, the Alberta government essentially engages in a kind of misrecognition or nonrecognition violative of Mr. Vriend's dignity and equality as a gay man and Canadian citizen. The case exemplifies powerfully how the "withholding of recognition can be a form of oppression." ${ }^{\text {"it }}$ But it also shows how, to overcome a liberalism that has traditionally advanced the principal of equal dignity and respect by cultivating obliviousness to human differences (and hence, relying upon notions of abstract individualism and formal equality), what Canada needs is a political culture wherein the concept of equal dignity is reconciled with the politics of recognition. Taylor suggests that this reconciliation might be achieved by introducing a more holistic individualism into Canadian political and legal ordering. This holistic individualism, in respecting the politics of difference and the necessity for tolerance, would contain "a universal

*1 Taylor, supra note 79 at 232. 
potential at its basis, namely, the potential for forming and defining one's own identity, as an individual and also as a culture."

By incorporating a more holistic view of the individual into political and legal analysis, some of the deficiencies of an atomistic, abstract individualism could be overcome, and the identities of sexual minorities like Mr. Vriend would be recognized as falling within the scope of human self-fashioning.

In combination with the insights of Fraser, Taylor thus argues on behalf of bringing a richer conception of human beings to bear in political and legal contexts. In effect, Taylor's holistic individual might be developed into a kind of "Charter person" whose rights and freedoms, as defined under the Charter, would deserve defending whenever violated. The holistic individual would be a more complex political subject capable of experiencing not only traditional physical or economic harms, but also harms to her or his human dignity. ${ }^{83}$ This concept of the holistic individual or Charter person could certainly be developed through an expansive reading of section 7 and section 15 of the Charter.

Taylor's views, juxtaposed with those of Fraser and Casswell, seem promising in terms of offering a way out of the problems associated with liberalism's abstract individualism in a case like Vriend. For what Vriend shows is that liberalism's difference-blind principle of equal dignity and respect frequently fails to protect minorities in Canadian society. Instead,

[I]t negates [their] identity by forcing [them] into a homogeneous mold that is untrue to them. This would be bad enough if the mold were itself neutral... But the complaint generally goes further. The claim is that the supposedly neutral set of difference-blind principles is in fact a reflection of one hegemonic culture. As it turns out, then, only the minority or suppressed cultures are being forced to take alien form. So the supposedly fair and difference-blind society is not only inhuman (because suppressing identities) but also, in a subtle and unconscious way, itself highly discriminatory. ${ }^{\text {st }}$

Judith Butler develops the point about the discriminatory effects of misrecognition (or nonrecognition) even further when, speaking about the "heterosexual imperative" as a regulatory force within contemporary society, she articulates the process by which psychological harm is produced in marginalized persons:

[The] exclusionary [heterosexual] matrix by which subjects are formed ... requires the simultaneous production of a domain of abject beings, those who are not yet 'subjects,' but who form the constitutive outside to the domain of the subject. The abject designates here precisely those 'unlivable' and 'uninhabitable' zones of social life which are nevertheless densely populated by those who do not

Ibid. at 236.

One can certainly see that the Supreme Court of Canada, in Butler, has contemplated this kind of harm as well as the possibility of construing individuals as Charter persons. In Butler, the argument was advanced that pornography, while it does not cause demonstrable physical harm to actual individuals, creates an atmosphere in which female members of society are inhibited from participating in the community because of the threat to their self-worth. 
enjoy the status of the subject, but whose living under the sign of the 'unlivable' is required to circumscribe the domain of the subject... In this sense, then, the subject is constituted through the force of exclusion and abjection.... ${ }^{\text {ss }}$

Butler's point is that the misrecognition or nonrecognition of particular individuals limits the scope of subjectivity - not only for them but for everyone. By adopting Butler's way of thinking, one can see how the law, by failing to acknowledge the special concerns and conditions faced by disadvantaged groups such as gays and lesbians, actually infringes upon the humanity of everyone. To paraphrase John Donne: one person's suffering and death diminishes everyone.

By contrasting the majority judgement of the Alberta Court of Appeal with the Supreme Court's response, one notices that Vriend exemplifies how the encumbered nature of human selfhood may be either suppressed or misrecognized in certain kinds of judicial comparisons and interpretations. McClung J.A.'s majority judgment for the Alberta Court of Appeal exemplifies how sexual orientation, and its bearing upon themes of substantive equality and discrimination, can be deliberately effaced by the liberal-legal rhetoric of abstract individualism and formal equality, thus permitting insidious forms of discrimination to go unrecognized and unredressed.

As we shall see, the Supreme Court's judgment, in contrast to that of McClung J.A., shows how the equality guarantees of the Charter may be used to modify its liberal political vision. The case provides an opportunity for re-evaluating the concepts and assumptions underpinning and dominating Charter jurisprudence and modernist jurisprudence in general, and for recognizing the contextual and situated nature of all legal thought and practice.

\section{INSIDE MCCLUNG J.A.'S "ClOSET"}

\section{A. Privacy as a tool of exclusion, Oppression, and Public Subordination}

McClung J.A.'s majority judgment for the Alberta Court of Appeal in Vriend ${ }^{86}$ is not only deeply indebted, logically and conceptually, to a private/public divide integral to classical liberalism, ${ }^{87}$ but also committed conceptually to a strict and narrow reading

ks Supra note 29 at 3.

N. Vriend v. Alberta (1996), 181 A.R. 16 (C.A.) [hereinafter Vriend (C.A.)].

«7 See J. Whyte, "Is the Private Sector Affected by the Charter?" in L. Smith et al., eds., Righting the Balance: Canada's New Equality Rights (Saskatoon: Canadian Human Rights Reporter Inc., 1986) 145 at 149, wherein White states the following:

[N]otwithstanding the analytic difficulties in setting limits on the Charter's application it would be wrong to conclude that the constitutional values found in it are meant to apply to, and control, private arrangements. This view is based on a perception of the political philosoplyy which the Charter of Rights embraces. It is this. There are two competing theoretical positions, the first of which is that the virtues of tolerance, respect, rationality, openness, and fair process should be promoted in respect of all social arrangements. The second is that, in our role as private persons we are not obliged to subscribe to, and lead our lives according to, 'state' virtues. The Charter adopts the latter. As difficult as it will be, the 
of Section 32 of the Charter. In ruling that the Alberta government has no obligation to include sexual orientation as a ground of discrimination under the Individual's Rights Protection $\mathrm{Act}^{88}$ - despite the recent ruling in Egan v. Canada, ${ }^{89}$ McClung J.A. essentially constructs and deploys an oppressive privacy argument to keep gays and lesbians in a "closet" reinforced by the difference-blind concepts of political liberalism. McClung J.A.'s "closet" - not his own, but the one he imposes on Delwin Vriend and other sexual minorities - is a private sphere carefully separated from the public sphere of explicit government action, such that what happens within the "closet" is kept outside the public sphere to which the Charter applies. Effectively, McClung J.A. argues that the Charter does not apply to the case of Delwin Vriend because there is no government action to trigger the Charter's application to events in the private sphere: "the omission of the phrase 'sexual orientation' by the elected law-makers of this province ... does not amount to governmental action for the purpose of s. 32(1) of the Charter." The argument ignores the fact that human rights legislation is designed to deal with violations that occur in the private as well as the public sphere." Indeed, McClung J.A.'s use of the private/public divide illustrates the soundness of the scepticism articulated by Allan Hutchinson and Andrew Petter with respect to the Charter's perpetuation of such a divide: "The public/private distinction is not an indifferent structure that provides a convenient framework for debating and deciding the distribution of political power. It skews that debate and prods its resulting decisions in particular directions."

McClung J.A.'s privacy rhetoric must be read in the context of Patricia Boling's insightful Privacy and the Politics of Intimate Life, ${ }^{93}$ which thoroughly explores various meanings and uses that privacy assumes in contemporary legal contexts. Boling recognizes that "privacy is connected etymologically both to people and issues that are deprived of public significance or office and to the notion of protecting private decision making...."94 That is, she understands that:

privacy is a double-edged sword. Sometimes it is good because it protects us from scrutiny and interference. But sometimes it is bad because it shuts off parts of our lives from public debate and prevents us from taking political action to improve those parts of our lives."

terms of the Constitution require that a line be drawn between conduct that is 'public' and subject to the Charter's constraints and conduct that is 'private' and free from the obligation to conform to the nation's constitutional standards.

R.S.A. 1980, c. T-2, am. S.A., 1985, c. 33, S.A. 1990, c. 23. This statute has since been amended: see Individual's Rights Protection Amendment Act, 1996, S.A. 1996, c. 25. This statute is now called the Human Rights, Citizenship and Multiculturalism Act, R.S.A. 1980, c. H-11.7. For the purposes of this article, I am referring specifically to the Individual's Rights Protection Act, since it was in place in 1992, at the time that Delwin Vriend made his claim.

[1995] 2 S.C.R. 513 [hereinafter Egan].

Supra note 86 at 22.

Casswell, supra note 75 at 3.

A. Ilutchinson \& A. Petter, "Private Rights/Public Wrongs: The Liberal Lie of the Charter" (1998) 38 U.T.L.J. 278 at 286.

P. Boling, Privacy and the Politics of Intimate Life (Ithaca: Cornell University Press, 1996).

Ibid. at ix.

Ibid. 
In juxtaposing McClung J.A.'s use of privacy in Vriend with Boling's astute analysis, one clearly recognizes "the ideological part privacy can play in hiding disparities in power and privilege, injustice and oppression...." Notice, for instance, how McClung J.A. builds his privacy argument on the assumption that all Albertans, whether homosexual or heterosexual, have equal opportunities to order their lives privately: "legislative silence remains an imperative of choice for the provincial legislatures, clearly so when their considered choice is to table questions of private activity to private resolution..."; 97 "homosexuals and heterosexuals may contract or decline to contract with each other without legislated incentives." 98 He pays no attention whatsoever to power imbalances within society that jeopardize or negate autonomy and freedom for some members of the population.

What is clear is that, through reading section 32 of the Charter as narrowly as he does, McClung J.A. wields privacy as a weapon; he uses it not as a means of protecting those like Delwin Vriend, who belong to "discrete and insular" minorities, but rather as a means of keeping people like Vriend in the "closet." And, when all is said and done, the "closet" is really just a special kind of prison, is it not?

The primary effect of McClung J.A.'s privacy argument is to "deprive issues, perspectives, and people of public recognition." And given that we have already learned, through the work of Casswell, Fraser, and Taylor, about the intimate connection between misrecognition (or nonrecognition) and the violation of human identity and dignity, there is more than a little inconsiderateness in McClung J.A.'s approach. He is seemingly blind to the sort of indignity and political harm his privacy argument imposes upon sexual minorities. He assumes that the law treats homosexuals and heterosexuals in a formally equal way just because the Individual's Rights Protection Act does not specifically address differences in sexual orientation. This sort of approach, however, in positing a false symmetry between homosexuals and heterosexuals, ignores or dismisses the discriminatory social and historical context in which gays and lesbians actually live, and the historical evidence of their regular subjection to harassment and abuse of a kind that most heterosexuals never face. McClung J.A. fails to acknowledge that the concerns and material conditions of gays and lesbians are relevant to the unequal treatment they receive in a society where the dominant voices automatically assume that everyone is heterosexual.

McClung J.A.'s privacy argument, then, implicitly treats the heterosexual experience as the norm against which sexual minorities are to be compared. His judgment perpetuates the harm of misrecognition that Vriend and others like him experience. According to McClung J.A.'s "logic," which postmodern jurisprudence certainly challenges, the "otherness" inherent in the voice and experience of Delwin Vriend does not register: Vriend and his kind must remain publicly silent and invisible; they may

Ibid. at 3.

Supra note 86.

lbid.

Boling, supra note 93 at 4. 
say and do what they want, but only in the soundproof "closet" of the private realm, which is a fiction erected to protect dominant interests that control the public sphere.

McClung J.A.'s strategy of forcing an oppressive privacy upon sexual minorities lends credibility to what Catherine MacKinnon says when she "relentlessly attacks the notion that private life is free from coercion and inequality." 100 By using privacy in this way, as a tool for nonrecognition and marginalization, McClung J.A. practices the kind of judicial "activism" attacked by Iris Young in Justice and the Politics of Difference, ${ }^{101}$ when she criticizes the creation of a neutral "public sphere" through seemingly impartial judicial reasoning. That seemingly impartial reasoning, in her view, actually perpetuates the exclusion and invisibility of minority voices and perspectives. As Boling notes, "[Young's] analysis of the power of a conceptual framework based on impartiality and the separation between public and private to validate certain kinds of reasoning and experience and marginalize others offers a new way to think about the ideological power of privacy...."102

Obviously, unlike Justice Blackmun of the U.S. Supreme Court, whose dissenting judgment in Bowers v. Hardwick ${ }^{103}$ invokes the value of privacy to promote individual autonomy and homosexual freedom, McClung J.A. uses the idea of privacy as a tool of exclusion in Vriend. His reasoning perpetuates the fallacious politics of misrecognition that Fraser, Taylor, and Butler all elaborate upon. The reasoning effectively imprisons and disempowers particular kinds of people without officially sentencing or punishing them. The reasoning censors "sexual" issues from legal discourse, thus preventing certain individuals and groups from attaining public recognition and respect. McClung J.A.'s exclusionary rhetoric reinforces traditional gender stereotypes, homophobia, and heterosexism; in that sense, his judgment perpetuates the regulatory norms - sexist and heterosexual - by which all people, whether straight or gay, are coerced. The privacy rhetoric, emphasizing an ideological compartmentalization of human experience, typifies modernist jurisprudence that cannot adjust or respond to an "otherness" hidden by the dominant discourse of law.

However, McClung J.A.'s judgment, and the "closet" he constructs for sexual minorities, is particularly vulnerable to the insights of legal postmodernism, which in its various configurations "submits the operations of the law to forms of scrutiny which aim to expose its blindness, inconsistency or concealed interests."104 Legal postmodernism, certainly in the form of the Critical Legal Studies movement, operates with "the aim of revealing the historicity, the constructedness and sometimes the sheer arbitrariness of rules and structure which legal theory assumes to be, or legal procedures persuade us to view as natural, permanent and essential." 105 When we examine McClung J.A.'s reasoning through the lens of postmodern jurisprudence, we

Ihid. at 9.

I. Young, Justice and the Politics of Difference (Princeton: Princeton University Press, 1990).

Supra note 93 at 12.

Bowers v. Hardwick (1986), 106 S. Ct. 2841.

Connor, supra note 14 at 64 .

Jbid. at 65. 
recognize that his judgment in Vriend (C.A.) constitutes a particularly ungenerous and intolerant form of liberalism - a non-neutral liberalism that ultimately contradicts itself. McClung J.A.'s liberalism is one of those "blind liberalisms" that actually reflect "particular cultures": that is, it is "a particularism masquerading as the universal." 106 The problem is that McClung J.A. does not realize that he is at a "dress-up party" of his own making; he does not recognize that he himself is wearing a costume, one that might appear ridiculous to others who are unlike him. His own "closet" is showing a little, so to speak. Insofar as McClung J.A. does not recognize his judicial "performativity" as evidence of the "reiterative power of discourse to produce the phenomena that it regulates and constrains," 107 he fails to recognize that justice requires the development of a non-violative relationship to "the other." McClung J.A.'s liberalism interpellates gays and lesbians as Minow's outsiders, thereby violating their dignity as human beings and censoring the narratives they have to share. His liberalism makes them into people whose stories are deleted from the public record. This liberalism discriminates by treating all people as if they were the same.

\section{B. AN ALlEgory OF Discrimination: AN "IDEOLOGY OF EQUALITY"}

As the above analysis of McClung J.A.'s judgment reveals, there is a particular ideology of privacy at work in the way he defends Alberta's under-inclusive human rights legislation. To read closely the words of McClung J.A. is to notice how his own reasoning embodies the very cloaked activism that he so fervently attacks in the lowercourt judgment of Russell $\mathrm{J}$. and in the recent jurisprudence of the Supreme Court of Canada. What makes McClung J.A.'s own position especially disingenuous is his strategy of characterizing it as natural, constrained, and neutral. In all his omniscience, he refuses to acknowledge his own partiality and politics, and so his partiality and politics become that much more repressive and venomous to the disadvantaged group(s) he refuses to recognize. He writes disparagingly of "legisceptical Canadian judges"; 108 of "constitutionally-hyperactive judges" with "appetites" that "grow with the eating"; 109 of judges who "wield" or brandish the Charter as if it were a knife; of judges who engage in "untranslatable processes of judicial carpentry"; 110 of judges whose "judicial solutions emerge clad in solemnity" while becoming as indisposable as "nuclear waste";" of judges who are "loosed" to roam freely in a "legislative pasture." 12 Such imagery makes for a visually rich judgment; however, it also reveals the antagonistic attitude of McClung J.A. with respect to his peers and the serious matter before the court. His imagery is perhaps especially telling in his allusions to war: "the Trojan horse of merely reading-up";113 "the creeping barrage of the specialinterest constituencies that now seem to have conscripted the Charter." 114 And his

\footnotetext{
Taylor, supra note 79 at 237.

Butler, supra note 29 at 2.

Supra note 86 at 26.

Ibid. at 26.

Ibid. at 31 .

Ibid. at 32.

Ibid. at 34 .

Ibid. at 33 .

Ibid. at 31.
} 
questionable sexual nuances register most significantly: "[i]n the search for the just Canadian equilibrium it was not expected that majority rights and interests would curtsy, endlessly, to minority rites"; 115 "more and more judges are lying back and enjoying it"; "16 "[u]nfortunately, the Court of Queen's Bench, by engaging in judicial mid-wifery, has... expanded the Act in a manner that is pleasing to its own eye." 117 These images and others construe the feminine as negative; they are suggestive and convey a less than neutral and objective attitude on the part of McClung J.A.

From the perspective of equality theory, then, it is unsurprising that McClung J.A. employs what Kathleen Lahey, in "Feminist Theories of (In)equality," refers to as an "ideology of equality." 18 Lahey explains what she means by this phrase:

\begin{abstract}
The more we all argue about the precise meaning or definition of equality, the more we all will come under the sway of the ideologies of equality - complex and interdependent sets of beliefs and interpretations of reality that lead us to describe what we see as equality simply because liberal political theory is coherent only when everyone is presumed to be equal. This presumption of ideology represses our understanding of what constitutes conditions of actual inequality, and thus transforms theories of inequality into ideologies of equality."
\end{abstract}

Lahey's essential point - and it is crucial to an understanding of McClung J.A.'s rhetoric - is that equality analysis dependent upon the conceptual apparatus of liberal political theory purposely understands equality in such a way as to ignore actual inequalities. That is, liberal political theory, dependent upon the idea of the "formal equality" of citizens, perpetuates an ideology of equality that not only ignores significant human differences but also assimilates equality analysis into a "discourse of domination." 120 In such analysis, the material conditions of inequality are effectively banished from legal analysis.

That McClung J.A. is engaged in such an "ideology of equality" is evident in the strict textualism with which he reads Alberta's statute: "[n]othing in the IRPA ... purports to draw distinctions between heterosexuals and homosexuals"; ${ }^{121}$ "[c]learly, the content of the IRPA, as it presently reads, is neutral, non-aligned and inclines to neither the homosexual nor the heterosexual communities. 'Sexual orientation' is not mentioned at all." 22 He refuses to acknowledge the history of discrimination that homosexuals and lesbians have experienced, and so he uses the concept of formal equality to reinforce inequalities based on differences in sexual orientation.

Ibid. at 37.

Ibid. at 34 .

Ibid at 37 .

K.A. Lahey, "Feminist Theories of (In)equality" in S.L. Martin \& K. Mahoney, eds., Equality and Judicial Neutrality (Toronto: Carswell, 1987).

Ibid. at 71-72.

Ibid. at 73 .

Supra note 86 at 22 .

Ibid. at 24. 
Lahey detects the "ideology of equality" in "paradigmatic modes of judicial thought — disguised as reason and packaged as analysis...." 123 These modes or techniques of thought include the following: 1) constructing a "false symmetry" between the equality claims of disadvantaged and dominant groups; 2) using legal reasoning to "withhold legal protection" from disadvantaged claimants "by invoking jurisdictional analyses"; ${ }^{24} 3$ ) applying "differential definitions of discrimination."125 In Vriend (C.A.) McClung J.A. adopts similar modes or techniques of analysis, with the intention of ignoring actual, historical inequalities. The abstract equality employed by McClung J.A., in keeping with the basic tenets of liberalism, "masks the actual inequalities in power, wealth, resources and abilities which exist between real individuals in liberal society."

\section{THE Charter's CONCEPTUal Dissonance: THE MAlaise OF ABSTRACT, UNENCUMBEREd Individualism and the Challenges of Substantive Equality}

What bears mentioning, in view of McClung J.A.'s use of ideologies of privacy and equality as weapons against sexual minorities, is that the Charter actually embodies conceptual tensions that focus on the limitations of political liberalism. The Charter's equality provisions exist in tension with its liberal underpinnings. Those provisions challenge the fundamental liberal proposition "that the good of the individual is the main focus of moral theory and social, economic and political institutions"; 127 those equality provisions challenge "liberalism's philosophical foundations and fundamental commitment to individual rights and liberties, minimal state intervention and neutrality between competing conceptions of the good." 28 Moreover, as the Charter's equality jurisprudence evolves, it is becoming clear that they are importing key postmodernist insights into Charter analysis, insights that result in modifications to the Charter's deep political structuring.

In particular, the equality provisions, because they enable the courts to focus on differences and inequalities through contextual analysis, allow the particulars of human experience to register in legal analysis. Such particulars are generally excluded from legal analyses founded upon liberalism's primary concepts: formal equality and abstract individualism. By emphasizing "the socially interdependent and socially constructed nature of the individual," the equality provisions of the Charter reveal "the inadequacy of the concept of the abstract individual as the starting-point for political explanation and analysis." 129

Supra note 118 at 72.

Ibid. at 75.

lbid.

M. Ramsay, What's Wrong with Liberalism? A Radical Critique of Liberal Political Philosophy (London: Leicester University Press, 1997) at 18.

lbid. at 4.

Ibid.

Ibid. at 32-33. 
In highlighting the difficulty of viewing the liberal state as "neutral between the different conceptions of the good life espoused by individuals...," 130 Vriend illustrates the need, within a democratic culture, for establishing, as Charles Taylor has recommended, "some commonly recognized definition of the good life...." shows that the law must do more than "arbitrate the competing demands of individuals"132 in the fashion of liberalism; rather, as in a classical republican regime, the law must encourage citizens to become "attached to the laws as the repository of ... dignity." ${ }^{133} \mathrm{He}$ also notes:

[T]he very definition of a republican regime as classically understood requires an ontology different from atomism, falling outside atomism-infected common sense. It requires that we probe the relations of identity and community, and distinguish the different possibilities, in particular the possible place of we-identities as against merely convergent l-identities, and the consequent role of common as against convergent goods. ${ }^{134}$

Taylor's view has potential in the Canadian context, since it is highly unlikely that Canada will retreat substantially from its emphasis on individualism and personal autonomy.

Nonetheless, in Canada the evolving equality jurisprudence of the Charter, especially insofar as it affirms the concept of substantive equality, is weakening the Charter's emphasis on abstract, atomistic individualism and the private/public divide. By examining the Supreme Court's reasoning in Vriend, one notices that there has been a discernible movement away from a strict distinction between legality and justice, and a recognition that the procedural legality of liberalism often unwittingly or insidiously excludes many of the deeper concerns inherent in substantive justice.

Charles Taylor's argument in favour of "holistic individualism" would appear to offer one possible viable alternative to abstract individualism; it is an alternative that eludes the major weaknesses of traditional liberalism. Taylor's holistic individualism sees individuals as the products of social interaction and dialogue, rather than as entities somehow made in isolation from each other and their community.

What is important about Taylor's holistic individualism - and this is crucial for understanding the jurisprudential significance of Vriend - is that it helps us to understand the fruitless nature of the battle between personal autonomy and substantive equality. Taylor suggests that, to promote genuine personal autonomy, we must concede the interdependence and social nature of all persons, and reinforce such interdependence through our legal and political systems without violating the privacy of selfhood. (Cambridge, Mass.: Harvard University Press, 1995) at 182. 


\section{THE SUPREME COURT'S ResPonse: THE SUPREMACY of EQuality AND A PHilosophy of InClusive Justice}

In overturning the majority decision of McClung J.A. of the Alberta Court of Appeal, the Supreme Court of Canada convincingly counters his exclusionary privacy argument, his ideology of equality, and his blind liberal attack on judicial activism. From reading the majority judgment written jointly by lacobucci and Cory JJ. and the supplementary statement on the Charter's equality provisions by L'Heureux-Dube' J., one can make several observations regarding the tensions between modernist and postmodernist jurisprudence in Canada's Supreme Court. Moreover, the judgment makes discernible a burgeoning philosophy of the Charter at the Supreme Court that might be worth keeping an eye on in the next several years.

Crucially, the Court characterizes Vriend as a case about the absence of public access to justice rather than a case focusing solely on a discrete event that has occurred in some cordoned-off private sphere: "[I]t is the denial of access to the complaint procedures of the Alberta Human Rights Commission that is the essential element of this case and not [Delwin Vriend's] dismissal from King's College."135 Access to justice, one should note, is a variation on the theme of political and legal recognition in the public sphere. The lack of access to justice is thus centrally related to the special kind of harm mentioned earlier in connection with the work of Casswell, Fraser, Taylor, and Butler.

In countering McClung J.A.'s privacy argument, the Supreme Court refines its stance with respect to of the Charter's application in matters that appear private as opposed to public in nature. The Court protects the idea of the private realm but simultaneously demonstrates how problems in the realm of private activity can easily attach themselves to governmental decisions and legislation:

The application of the Charter to the IRPA does not amount to applying it to private activity. It is true that the IRPA itself targets private activity and as a result will have an 'effect' upon that activity. Yet it does not follow that this indirect effect should remove the IRPA from the purview of the Charter. ${ }^{13,}$

To put to rest any lingering doubts, Cory J. asserts that " $[t]$ he constitutional challenge here concerns the IRPA, an Act of the Alberta Legislature. It does not concern the acts of King's College or any other private entity or person." ${ }^{137}$ What is crucial, however, is that by declaring its intention to scrutinize the substance rather than the form of legislation, the Supreme Court gives itself room to consider the particular context, historical or personal, of any constitutional challenge. Legislative omissions or failures to act can, in this way, be construed as governmental decisions of a kind. Within Cory J.'s analysis some weight is given to the idea that the state might have to assume positive obligations in particular kinds of situations in order to uphold the Charter: "in 
some situations, the Charter might impose affirmative duties on the government to take positive action." 138 While no comprehensive statement on such duties is ultimately offered, the significance that such duties would have in upholding positive rights rather than negative rights is noteworthy. Maureen Ramsay makes that significance quite clear:

The individual [who] is the subject of positive rights claims is a social interdependent being with needs that can only be intersubjectively realized; this individual requires for their survival and reproduction the co-operation, help, support and productive efforts of other people. According to this view, rights are not individual claims against isolated, antagonistic, self-interested and competitive individuals. Rights and their corresponding duties to avoid harm, protect and aid are organizational, co-ordinating devices which reflect our interrelatedness...."

As Ramsay suggests, to expand the scope of positive obligations within society is to move beyond the separateness of individuals that is sacrosanct to classical liberalism.

In countering McClung J.A.'s ideology of equality, the Supreme Court makes it absolutely clear that substantive rather than formal equality is what Section 15 of the Charter is intended ultimately to defend: "the IRPA in its underinclusive state denies substantive equality...." And so the court must pay attention to legislative omissions and silences that might, under the guise of formal equality, perpetuate insidious forms of discrimination: "[i]f mere silence of the legislation was enough to remove it from s. 15(1) scrutiny then any legislature could easily avoid the objects of s. 15(1) simply by drafting laws which omitted reference to excluded groups." ${ }^{\prime 41}$ In support of that position, Cory J. cites the following words of Dickson C.J. in Brooks v. Canada Safeway Ltd: "Underinclusion may be simply a backhanded way of permitting discrimination." 42 Another, more recent case, Eldridge v. British Columbia (A.G.), ${ }^{143}$ is cited in support of the concept of substantive equality: "[t]here the Charter's requirement of substantive, not merely formal, equality was unanimously affirmed. It was, as well, recognized that substantive equality may be violated by legislative omission." 144

In the Supreme Court's view, Vriend is thus clearly a case in which a person from a disadvantaged minority is denied the equal benefit and protection of the law. The underinclusiveness of Alberta's human rights legislation operates in a discriminatory and exclusionary fashion. The Court's analysis seems receptive to the "otherness" that is "beyond" the law, and the emphasis on publicly recognizing the needs and perspectives of disadvantaged groups seems uppermost in the Court's reasoning.

\footnotetext{
I3k Ihid. at 534.

(11) Supra note 126 at 164.

INII Supra note 10 at 542.

(s) Ibid. at 541 .

Hz [1989] I S.C.R. 1219 at 1240.

143 [1997] 3 S.C.R. 624.

ist Supra note 10 at 542 .
} 
In this connection, Cory J. focuses insightfully on the harmful effects of exclusionary legislation:

\begin{abstract}
The exclusion sends a message to all $\mathrm{Albertans}$ that it is permissible, and perhaps even acceptable, to discriminate against individuals on the basis of their sexual orientation. The effect of that message on gays and lesbians is one whose significance cannot be underestimated. As a practical matter, it tells them that they have no protection from discrimination on the basis of their sexual orientation. Deprived of any legal redress they must accept and live in constant fear of discrimination. These are burdens which are not imposed on heterosexuals.
\end{abstract}

Perhaps the most important is the psychological harm which may ensue from this state of affairs. Fear of discrimination will logically lead to concealment of true identity and this must be harmful to personal confidence and self-esteem. Compounding that effect is the implicit message conveyed by the exclusion, that gays and lesbians, unlike other individuals, are not worthy of protection....

The law confers a significant benefit by providing state recognition of the legitimacy of a particular status. The denial of that recognition may have a serious detrimental effect upon the sense of selfworth and dignity of members of a group because it stigmatizes them.... ${ }^{\text {is }}$

I have quoted this passage at length because it seems to embody what I would describe as a burgeoning philosophy of the Charter, a philosophy of inclusive justice reflective of postmodern concerns with the stories of outsiders and the "philosophy of the limit." The passage certainly comments in some detail on the special kind of harm that legal systems as regulatory mechanisms can impose upon the citizenry of a country. In describing this sort of law-induced harm, the Supreme Court is postulating, as postmodern jurisprudence does, that the law works to produce the reality in which we live, not merely to reflect it.

In her separate statement on s. 15 of the Charter, L'Heureux-Dubé J. shows herself to be the Court's strongest advocate of a Charter philosophy built upon the values of equal dignity and recognition. She unequivocally reiterates the position she took in Egan with respect to the philosophical significance of equality in the Charter: "At the heart of s. 15 is the promotion of a society in which all are secure in the knowledge that they are recognized at law as equal human beings, equally capable, and equally deserving."146 L'Heureux-Dube's philosophy of Section 15, in which she argues against a narrow, analogous-grounds approach, might also serve as a philosophy for the Charter as a whole, especially in the light of the works of others such as Nancy Fraser, Charles Taylor, and Judith Butler.

\title{
VII. EPILOGUe
}

In the end, one must return to the question raised earlier about whether the Supreme Court of Canada has a deep philosophy of the Charter. Are legal experts justified in expressing dissatisfaction with the Supreme Court's Charter jurisprudence?

146. As quoted in Vriend (S.C.C.), supra note 10 at 580. 
As my analysis of Vriend shows, the Supreme Court of Canada is working towards a philosophy of the Charter that supercedes the words of Sopinka J., who once said, somewhat reductively: "The role of the Charter is to protect the individual against the coercive power of the state." 147 At the centre of the philosophy that the Court is striving to articulate is the ideal of equal dignity and recognition for all Canadians. Given the prominence of equality in such an ideal, I think it may be time to acknowledge that equality is becoming the supreme Charter value in Canada, despite the fact that the Supreme Court has held that there is no hierarchy of rights in Canada. Other values like the freedom of religion and the freedom of expression have been defined in such a way as to make equality seem foundational. ${ }^{148}$ As one critic recently put it, "[t]he value of equality is ... of such importance that it might be termed a supravalue."149

In any case, while the Supreme Court's judgments may appear to be "all over the map," it does seem clear that the equality provisions of the Charter, as a case like Vriend demonstrates, are providing a means for postmodern jurisprudence to "infiltrate" Canada's highest court. The equality provisions, especially as described by L'HeureuxDubé J., who opposes the analogous-grounds approach, seem to keep Canadian legality responsive to the "beyond" of justice. To the extent that the "otherness" of disadvantaged groups like gays and lesbians becomes recognized by the law, justice in Canada takes on an inclusive, postmodern air, and withdraws from the exclusionary tactics of modernist jurisprudence. Inside McClung J.A.'s closet, a dimly lit chamber of horrors, we have found judicial implements and tactics that exclude and degrade those who are vulnerable. Inside the Supreme Court of Canada, we see that different tools are now in use. As Abella J.A. has put it, Section 15 of the Charter is a "formidable social tool."150

Why are we here?

To be something new, to make a difference, in the wilderness of power and pain, in the arenas of exploitation and humiliation. Only this process of engagement can exalt and exhilarate us. We may not be able to prevent suffering, or degradation - we may not be able to stop the insufferable arrogance and insensitivity of those who purport to lead and manage us - but we may be able to make all of this less the case. So we must be tough visionarics, keen and reasonable, daring tragedy, aware of our propensity for apathy, ignorance, avarice, and savagery. Then we may say that Canada's hidden destiny is to follow a path that diverges from egotism and violence, and to build a place where people could

McKinney v. University of Guelph, [1990] 3 S.C.R. 229 at 444.

One could, of course, assert that the effectiveness of equality as a Charter value is actually highly dependent on freedom of expression, which is what makes the recognition of differences and inequalities possible. It is worth mentioning that there is a kind of censorship at work not only in McClung J.A.'s judgment in Vriend (C.A.) but also in the Alberta government's decision not to include sexual orientation as a ground of discrimination in the Individual's Rights Protection Act. T. Quigley, Procedure in Canadian Criminal Law (Scarborough: Carswell, 1997) at 48. R.S. Abella, "The Dynamic Nature of Equality" in S.L. Martin \& K. Mahoney, eds., Equality and Judicial Neutrality (Toronto: Carswell, 1987) at 3. 
say, 'All the forces and contradictions, the qualities and contrasts of our souls exist here side by side.' Maybe then we will be able to wholly imagine the alternative current, perceive that we are evolving a state without walls, and comprehend how we are pioneering a society whose communications stories express the myths of receptivity and constant negotiation, the anonymous place, the many-sided state, the pluralistic country without a single identity. ${ }^{\text {sI }}$ 